\title{
The biochemistry behind biopesticide efficacy
}

\author{
Michelle Hubbard, Russell K Hynes*, Martin Erlandson and Karen L Bailey
}

\begin{abstract}
Biopesticides have the potential to play an important role in sustainable, environmentally safe pest control. A diverse range of biopesticides employ chemical modes of action. This review explores three such biopesticides: a fungus used in weed control, beneficial bacteria controlling fungal and bacterial disease and a virus active against insect pests. Through these case studies, we demonstrate that biopesticides rely on both chemical and biochemical approaches and complementary biological modalities. Hence, biopesticides are more complex than synthetic pesticides. The latter typically utilize a single chemical with a single mode of action, while the former often have more complex or holistic modes of action. The success of current and future biopesticides could be enhanced through increased research focusing on the chemistry involved.
\end{abstract}

Keywords: Biopesticide, Bioherbicide, Biofungicide, Bioinsecticide, Secondary metabolites, Mode of action

\section{Introduction}

Biopesticides are attracting global attention as new tools to kill or suppress pest populations such as weeds, plant pathogens and insects while posing less risk to people and the environment than synthetic pesticides [1]. Globally, the use of biopesticides has steadily increased by about $10 \%$ per year [2]. Biopesticides are typically derived from living organisms, of plant or microbial origin; this paper focusses only on the latter. More than 225 microbial biopesticides are manufactured in 30 countries in the Organization of Economic Development and Cooperation [3]. The NAFTA countries (USA, Canada, and Mexico) use about $45 \%$ of all biopesticides sold, the European Union uses 20\%, Oceanic countries use 20\%, the South and Latin Americas use 10\%, and India and Asia use 5\% [4].

Bacillus thuringiensis has dominated the bioinsecticide marketplace since the 1950s. This organism is used on 75\% of the crops and forests in North America to control a wide variety of insect pests [4]. In the 1980s, Colletotrichum gloeosporioides (Penz.) Sacc. f. sp. aeschynomenes, Phytophthora palmivora Butler, and C. gloeosporioides f. sp. malvae were developed as bioherbicides for northern jointvetch, strangler vine, and round-leaved mallow, respectively. In the 1990s, Streptomyces griseoviridis was among the first biofungicides available for controlling root-infecting fungi in greenhouse crops. Despite the

\footnotetext{
* Correspondence: russell.hynes@agr.gc.ca

Agriculture and Agri-Food Canada, Saskatoon Research Centre, 107 Science Place, S7N 0X2 Saskatoon, SK, Canada
}

pressure for new biopesticides $[5,6]$. The rate of commercial success is less than $10 \%[7,8]$. The challenges facing researchers have usually been biological, environmental, technological and commercial constraints [9]. The question of how we can improve the chances of success remains.

The mode of action of a biopesticide is a critical component in commercial success. It determines efficacy of pest control, efficiency of use, consistency of response, host target and nontarget susceptibility. Mode of action also impacts the choice of manufacturing method and the final cost of production. Typically, there are three broad modes of action for microbial biopesticides: i) biological or ecological modes of action, ii) physical means, or iii) chemical or biochemical processes. Biological modes of action can include predation or competition. Physical control may involve creating barriers or occupying space. Chemical or biochemical approaches disrupt biochemical, genetic or structural function in the targeted pest. Glare et al. [5] reported that more successful biopesticides utilize compounds that are produced by the microorganism, rather than relying only on the infection process. Glare et al. [5] gives examples such as $B$. thuringiensis and B. subtilis, which produce toxic proteins and agrastatins, respectively. The production of these compounds has been optimized through fermentation. Biopesticides that utilize secondary metabolites may be more akin to synthetic pesticides. However biopesticides 
utilize multiple modes of action, greatly reducing the risk of resistance developing. For example, a single biopesticide may produce more than one secondary compound [10] that works synergistically with the physiological interaction of the microbe with the host. In contrast, pest resistance is a major concern [1] associated with synthetic pesticides which often rely on a single mode of action.

This review will focus on biopesticides that employ chemical or biochemical modes of action. Specifically, we will survey three examples of biopesticides - a fungal bioherbicide, a bacterial biofungicide and viral bioinsecticide whose modes of action are at least partially known. Through these three case studies, we will explore the importance of understanding and using chemistry and biochemistry in effective biopesticides.

\section{Three case studies of biopesticides that use chemistry The bioherbicide Phoma macrostoma}

Phoma macrostoma Montagne is a bioherbicidal fungus, meaning that it can be used to control undesirable weedy plants. P. macrostoma produces photobleaching symptoms in a wide range of broadleaf weeds, such as Canada thistle (Cirsium arvense (L.) Scop.), dandelion (Taraxacum officinale Weber ex F.H. Wigg.), chickweed (Stellaria media (L.) Vill.), and scentless chamomile (Matricaria perforata Merat). Monocots such as turfgrass, wheat and barley are unaffected by $P$. macrostoma $[11,12]$. A critical component of $P$. macrostoma phytotoxicity is the production of two structurally related secondary metabolites known as macrocidins A and Z (Figure 1) [13]. Macrocidins inhibit carotenoid biosynthesis in susceptible plants (unpublished data), inducing chlorosis, bleaching and eventual plant necrosis $[13,14]$. The individual roles of each of the four macrocidins are currently unknown. In addition to producing macrocidins, $P$. macrostoma enters weed tissues via locations adjacent to root hairs, colonizing intercellularly beside the vascular trachea, thereby interfering with tissue functionality [15]. P. macrostoma

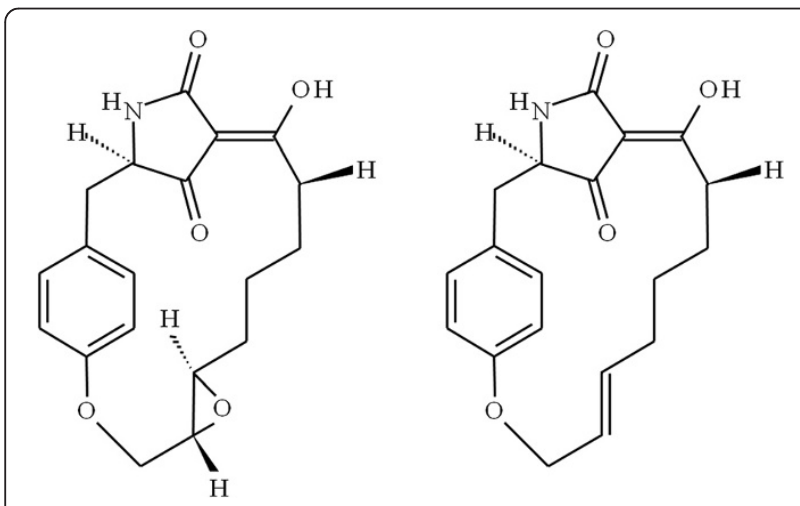

Figure 1 Two major groups of macrocidins: Macrocidin A (left, Graupner et al. [13]) and Macrocidin Z (right, Bailey et al. [16]). also colonizes resistant plants, albeit at a greatly reduced hyphal density and only in the outer layers of the root [15]. The physical colonization of the host plays a quantifiable role in bioherbicide effectiveness. The weed control achieved by a formulation containing both living P. macrostoma and macrocidins is decreased by roughly 15 to $20 \%$ by autoclaving which kills the fungus, but does not degrade macrocidins (unpublished data).

Identification of macrocidins provided inspiration and a starting point for future research. For example, the development of sensitive reverse phase liquid chromatography macrocidin detection systems [13] facilitated the work of Bailey et al. [17]. The latter work explored the water-solubility of macrocidins and the impact of potential rainfall events on run-off of macrocidins. Bailey et al. [17] discovered that the susceptibility of macrocidins to leaching and movement to non-target locations is dependent on saturated conditions and soil type. This information facilitates informed decision making about when and where to apply P. macrostoma-based formulations, leading to a more useful bioherbicide and better efficacy.

The realization that higher levels of macrocidins in P. macrostoma formulations correlated with improved weed control point toward new strategies for developing a bioherbicide that would be more effective at lower doses, and hence more cost-efficient. Such strategies include elucidating fermentation and growing conditions under which macrocidin production can be increased, strain selection for naturally-occurring genotypes or genetic/epigenetic manipulation of $P$. macrostoma to generate a "super-producer". Modifications of $P$. macrostoma that avoid the need to release an organism carrying heterologous DNA could be prioritized in order to avoid potential concerns surrounding genetically modified organisms (GMOs) [5]. For example, de Crecy et al. [18] have used so-called "directed evolution" to enhance fungal tolerance for high temperatures.

The knowledge that macrocidins work by inhibiting carotenoid biosynthesis could also prove useful. For example, carotenoid-protective ingredients could be avoided in formulations. Additionally, factors that enhance localization of macrocidins to leaves (where carotenoid biosynthesis occurs) might be considered. A more complete understanding of how macrocidins interfere with carotenoid biogenesis could further expedite formulation development, or at least suggest avenues for future research.

Inhibition of carotenoid biosynthesis in general is a mode of action shared by macrocidins and various synthetic herbicides such as norflurozon, fluridone and diflufenican $[19,20]$. However, the way(s) in which macrocidins impact this process appear to be unique from, and more complex than, the modes of action of known synthetic 
herbicides (unpublished data). Hence, P. macrostoma could provide a valuable alternative to control weeds with resistance to carotenoid biosynthesis targeting synthetic herbicides. Phytotoxins produced by some plant pathogenic fungi are harmful to animals and/or humans [21]. Berestetskiy [21] gives examples such as Aspergillus fumigatus, Alternaria tenuissima, Penicillium spp. and Fusarium spp., all of which produce harmful mycotoxins. However, macrocidins and P. macrostoma are safe for humans, animals and the environment, effective against a wide range of weeds and have a long shelf-life [8]. Hence P. macrostoma and its secondary metabolites are a good choice for urban lawn and golf course weed control. In 2011 and 2012, P. macrostoma was registered for broadleaf weed control in turfgrass in Canada and the USA, respectively.

\section{The biofungicide Bacillus subtilis}

Bacillus subtilis is a vital component of the biopesticide strategy for crop disease management. A unique characteristic of $B$. subtilis is its ability to undergo differentiation from a vegetative cell to a highly resistant spore following exhaustion of an essential nutrient i.e. carbon, nitrogen or phosphorus or development of another unfavorable condition. B. subtilis is a Gram positive rodshaped bacterium, ubiquitous in nature and produces endospores [22,23]. These spores can withstand a high degree of exposure to desiccation, radiation (UV and gamma), moist and dry heat and oxidizing agents [24]. The robust nature of the $B$. subtilis spore and long shelflife is not lost on the biopesticide industry wishing to commercialize unique isolates with strong antagonistic activity to agricultural phytopathogens [25].

Bacillus subtilis are isolated from numerous environments including the rhizosphere (a zone enriched with nutrients from plant root exudation), where they effectively compete with diverse microbial population to establish micro-colonies and biofilms on plant roots [22,26,27]. Secreted toxic metabolites play a vital role in B. subtilis establishing a niche in the rhizosphere. B. subtilis produce antimicrobial metabolites that target many bacterial and fungal soil inhabitants including plant pathogens, thus providing $B$. subtilis with a competitive advantage in nutrient limited niches [28]. B. subtilis are also beneficial to plants in that they promote plant growth through phytohormones production, sequestration of nutrients, stimulation of systemic induced resistance in plants and suppression of plant pathogen activities [26,29-31]. Antimicrobial metabolites from B. subtilis have been employed in biocontrol and plant protection by exploiting their antibiosis activity on phytopathogens [32]. These compounds also stimulate the plant's defense systems to pathogens by inducing systemic resistance in bean, Phaseolus vulgarus, and tomato, Solanum lycopersicum, [33,34]. Hence, B. subtilis can increase plant ecological fitness through sustained colonization of the rhizosphere [35]. The scope of this section will be limited to specific antimicrobial peptides produced by of $B$. subtilis, proposed function and implications.

Production of antimicrobial peptides appears to be universal among Bacillus spp. B. subtilis isolates are well represented in the literature in terms of discovery, chemical structure and host activity of these products of secondary metabolism (see reviews by Abriouel et al. [22], Jourdan et al. [34], Romero et al. [36], Stein [37], Ongena and Jacques [38], Kinsella et al. [39] Willey and van der Donk [40]). Kunst et al. [41] determined that $4 \%$ of the $B$. subtilis genome was associated with secondary metabolism. Stein estimates that $4-5 \%$ of B. subtilis genome was devoted to antibiotic production [37].

More than two dozen antimicrobial peptides have been discovered from collections of several hundred naturally occurring B. subtilis isolates [37]. These antimicrobial peptides are synthesized by two distinct systems; 1 . non-ribosomal peptide synthesis, ex. cyclic lipopeptides, iturin and fengycin families (see [33]), 2. ribosomal peptide synthesis, which are further subdivided into i) posttranslationally modified, ex. subtilin, ii) non-modified, ex. thurincins, and iii) large heat-labile proteins [22]. Antimicrobial peptide synthesis is closely regulated and reliant on both environmental conditions and B. subtilis growth phase.

A large collection of peptide synthetases constitute the non-ribosomal biosynthetic machinery that produces a diverse array of lipopeptides (LPs), such as iturin, fengycin and surfactin families. The LPs are amphiphilic and have cell wall and membrane surface active properties, facilitating the formation of pores in membranes of phytopathogenic bacteria and fungi. Loss of cell membrane integrity causes a disruption in active transport (i.e. nutrient and ion transport) leading to cell death. In vitro studies have demonstrated that surfactins have anti-bacterial activity, while iturins and fengycins have anti-fungal properties [38]. These in vitro findings support the hypothesis that B. subtilis kills and suppresses deleterious microorganisms in the rhizosphere and provide protection to plants. In a field study, surfactin and iturin were quantified by HPLC-MS from rhizosphere extractions of B. subtiliscolonized cucumber [39]. Levels of surfactin and iturin peaked on roots of 29 day-old cucumber at 60 and $1000 \mu \mathrm{g} / \mathrm{gram}$ fresh weight of root respectively [39]. In a study of $B$. subtilis mutants deficient in surfactin production, Blais et al. [35] reported that colonization and biofilm development on Arabidopsis roots was impaired and that infection of Arabidopsis roots by Pseudomonas syringae was not suppressed as compared to roots colonized by wild type B. subtilis capable of biofilm development. Optimum biocontrol activity and colonization of the rhizosphere by B. subtilis requires coordinated production and synergy 
of complementary LPs [33]. However, recent studies suggest that surfactin may also be a signal molecule in the quorum-sensing (QS) system in B. subtilis. Surfactin may be involved in initiating biofilm development by sub-populations of the colony and detection of microbial community diversity in the rhizosphere [36]. In general, QS molecules elicit regulation of genes required for microbial survival and act as microbial interspecies communication signals [42]. Therefore B. subtilis surfactins may have a role in communication and survival strategies in addition to their biocontrol activities.

B. subtilis also produce antimicrobial metabolites bacteriocins - by ribosomal peptide synthesis. Ribosomal syntheses uses the polyketide synthase gene cluster to produce a large assortment of bacteriocins (see reviews and chemical structures in Stein [37] and Abriouel et al. [22]). Abriouel et al. [22] propose a classification scheme of the Bacillus spp. bacteriocins that includes posttranslationally modified peptides, linear and globular-type lantibiotics, non-modified peptides and large proteins (see review on lantibiotics by Wiley and van der Donk [40]). Several of the lantibiotics display varying degrees of heat and $\mathrm{pH}$ stability, potentially attributable to the disulfide bonds in the individual molecules. B. subtilis produce the well-characterized lantibiotic subtilin, a post-translational modified 32-residue peptide. Subtilin is produced in response to environmental stressors such as decreasing nutrients levels. Subtilin exhibits broad spectrum activity towards Gram-positive bacteria by disrupting membrane function. This differs from activities of bacteriocins produced by Gram-negative bacteria in that the latter have a narrow killing spectrum [43]. Gram negative bacteria that become targets of $B$. subtilis lantibiotics undergo subtle changes in the amino acid composition [44].

Conventional pesticide residues on food and in the environment and resistance to them by plant pathogens have promoted interest in the development of alternative means of controlling crop diseases. B. subtilis isolates are desired for biofungicidal products because of the extensive portfolio of LPs and bacteriocins, status as a safe handling microorganism (generally regarded as safe, GRAS) and long shelf-life [25]. In addition, our understanding of the benefits of $B$. subtilis in the rhizosphere continues to expand. For example, Rudrappa et al. [45] illustrated the sophistication of the B. subtilis-Arabidopsis thaliana interaction, showing that B. subtilis colonized and formed biofilms on the roots following secretion of L-malic acid from roots after application of the foliar pathogen, Pseudomonas syringae. Furthermore, within the context of medical research, additional triggers or stress factors are being sought to increase production of antimicrobial peptides from B. subtilis. Nur Aishah et al. [46] reported that sub-inhibitory levels of extracts of garlic, Allium sativum, induced the production of antimicrobial peptides from B. subtilis 21332 . The ability to secrete an array of antagonistic and plant-benefiting compounds into the rhizosphere and form highly resistant spores establishes $B$. subtilis as a highly desirable biopesticidal product for crop production systems [6].

\section{The bioinsecticidal nucleopolyhedroviruses}

Insects constitute major pests of food and fiber production in the agricultural and forestry sectors as well as acting as vectors for many disease organisms, infecting plants of agricultural importance, as well as animals and humans. Insect pest control has relied primarily on the use of broad-spectrum chemical pesticides. In addition to negative human health and environmental effects related to chemical insecticides, their heavy usage has led to the emergence of secondary pest problems due to the loss of arthropod natural enemies and the development of resistance in insect pest populations to chemical insecticides. As a result, more environmentally sustainable pest control strategies have been proposed, notably integrated pest management (IPM). IPM incorporates a range of control tactics including cultural methods, judicious use of chemical insecticides, and biological control agents to suppress insect pest populations below levels that cause economic damage. Biological control agents include microbial pathogens of insects. Microbial insect pathogens are attractive for IPM systems due to their narrow host range. Currently microbial pest control products constitute only about $1.5 \%$ of the world wide pesticide market and microbial insecticides are dominated by Bacillus thuringiensis (Bt) based products $[47,48]$. Viruses are associated with insects in a wide range of ecological relationships as pathogens and as specialized symbionts that allow hymenopteran parasitoids to fully develop in their hosts (e.g. polydnaviruses). In addition, many plant and animal viruses rely on insect vectors for transmission. A number of virus families have been investigated as insect control agents. Viruses in the family Baculoviridae have been shown to have by far the greatest potential as bioinsecticides [49].

Baculoviruses have long been recognized as potential candidates for biopesticides because of their readily observable symptomology, their ability to produce impressive epizootics in insect populations and because they are detectable by light microscopy as a consequence of being occluded in relatively large protein crystals, referred to as occlusion bodies (OBs), within infected host cells. Currently, a number of baculoviruses are registered as insect control products worldwide [49]. Most of the registered baculovirus products are for control of lepidopteran and sawfly forest pests but a few have been developed as highly successful biopesticides to control lepidopteran pests in agriculture $[49,50]$. 
Baculoviruses are characterized by rod-shaped enveloped virions and a circular, dsDNA genome of $80-180$ $\mathrm{kbp}$. The family Baculoviridae is also defined by 37 core genes that are conserved in all baculovirus genomes [51]. This set of core genes provides a picture of the common elements required for functional baculoviruses including virion structure, novel polymerases required for virus-specific-DNA replication and gene transcription, and per oral infectivity factors that are essential for infection of insect midgut cells [50]. Their host range is restricted to arthropods and most particularly to insects [50]. Thus baculoviruses are considered to be very safe options for insect pest control. These viruses are infectious orally and the occlusion-derived virions (ODV) infect midgut epithelial cells after ingestion and dissolution of the $\mathrm{OB}$ in the alkaline condition of the midgut. Typically, two virion phenotypes occur in baculovirus infections, ODV and budded virions (BV) that spread the infection to tissues throughout the host. Thus the ODV are responsible for horizontal transmission between insect hosts and BV for systemic spread of infection within a host.

Baculoviruses kill their hosts by virtue of a complex replicative cycle that usurps the metabolic machinery of the host cell and diverts it to the production of baculovirus nucleic acids and structural proteins for virus production. No toxins per se are expressed during replication thus the speed of kill of hosts by baculoviruses is slower than other biopesticides such as typical $B$. thuringiensis strains which produce $\delta$-endotoxins. However, baculoviruses encode a number of proteins and enzymes that enhance their ability to specifically infect and replicate to high levels in insects and to increase the efficiency of spread and persistence of viruses with in the host insects' environment. A few of these key genes will be reviewed.

All baculoviruses encode an occlusion body protein (polyhedrin or granulin) which forms the bulk of the proteinaceous crystal or $\mathrm{OB}$ that occludes the virions in the later stages of virus replication. The OBs are responsible for the highly stable nature of these viruses in the environment. While the occluded form of the virus is susceptible to UV inactivation, in the soil the occluded virions can remain viable for several years. The OB protein, polyhedrin, can make up to $30 \%$ of infected cell protein and indeed the powerful promoter element of this gene was the initial basis for the development of baculoviruses as a eukaryotic gene expression system [52]. Upon ingestion of baculovirus OB by a host insect larva, the $\mathrm{OB}$ structure and polyhedrin protein is degraded in the alkaline environment of the insect midgut which also includes a diverse mixture of digestive proteases. The process releases the infectious occluded virions into the midgut lumen. However, to infect the midgut epithelial cells the virions must transit the peritrophic matrix (PM), a chitin and glycoprotein layer which lines the midgut lumen of most insect groups [53]. The PM is a physical barrier that protects the underlying midgut epithelial cells from abrasive food particles, digestive enzymes and pathogens that are infectious per os. A number of baculoviruses encode a family of metalloproteases referred to as "viral enhancing factor" or "enhancins". These metalloproteases are associated with the $\mathrm{OB}$ or are incorporated into the envelope of the occluded virion [54,55]. Enhancins have been demonstrated to increase the oral infectivity of baculoviruses from 2 to 15 fold when present at normal levels in OB or ODV $[55,56]$. The potential mode of action of "viral enhancing factor" (VEF) has been investigated using purified VEF proteins and recombinant viruses expressing VEF. The major impact observed is the degradation of the structural integrity of the PM [57]. More detailed studies have shown that VEF specifically degrades key structural glycoproteins of the PM, namely the insect intestinal mucins, leading to changes in the PM structure [58,59]. These degradative changes in the PM lead to more efficient transit of infectious ODV across the PM to the susceptible midgut epithelial cells and thus enhanced infectivity.

While baculoviruses encode a number of proteins and enzymes that interact with host cell machinery to maximize virus replication, one of the most interesting virus encoded enzymes interacts directly with the metabolism of a key insect hormone, ecdysone, which triggers molting in insects. Most baculoviruses infecting Lepidoptera encode an enzyme referred to as ecdysteroid UDP-glucosyltransferase (EGT) (reviewed in Rohrmann [50]). EGT catalyzes the transfer of glucose from UDPglucose to ecdysone thus inactivating the hormone and blocking the molting process from one larval instar to the next. Molting in insects is an energy intensive process and as a result pathogen-infected insects often die in the process of molting. By blocking the molt, the action of viral EGT extends the life span of a baculovirus infected larva within an instar and leads to the production of more virus OBs. Indeed, the production of $\mathrm{OB}$ in wild-type baculoviruses was shown to be approximately $30 \%$ greater than in a recombinant baculovirus in which the EGT gene had been deleted [60]. Interestingly, the EGT deletion virus killed infected larvae significantly faster than the wild-type virus because molting was not blocked and the insects died in the process of molting. It has been proposed that development of recombinant baculoviruses with the EGT gene under the control of an inducible promoter which would allow for production of OB in factory produced insects but would be EGT minus under "field" conditions could lead to baculovirus-based bioinsecticides with faster speed of kill.

Two of the observable symptoms associated with baculovirus infection in insect larvae are possibly linked 
to the evolution of pathobiology that ensures maximal dispersal of the virus within the host's environment, thus increasing the chances of epizootic development in host insect populations. It has long been recognized that baculovirus-infected-larva show an increased predilection to wandering and climbing behaviour (reviewed in Cory and Myers [61]). Indeed, some of the earliest reports of baculovirus infections refer to "tree top disease" describing the tendency for infected larvae to climb to the tops of the plant canopies and die. The infected cadavers hang clinging to plant tissue, become flaccid and begin to "melt". Several viral encoded enzymes play a role in this process which leads to increased dispersion of baculovirus $\mathrm{OB}$ in the host's environment. Both baculovirus EGT and a gene encoding a protein tyrosine phosphatase have been implicated in the hyperactivity and wandering behaviour seen in infected lepidopteran larvae. The evidence for the involvement of these enzymes in the altered behaviours comes from studies comparing wild-type and gene deletion virus infections $[62,63]$. The "melting" phenomenon has been linked to two virus encoded enzymes that facilitate the degradation of host tissues late in virus infection (reviewed in [50]). Chitinase genes are found in almost all baculoviruses infecting lepidopteran insects. This gene is expressed late in the baculovirus infection cycle and the enzyme is retained in the endoplasmic reticulum until infected cells begin to lyse. Chitinase is responsible for the digestion of chitin, one of the major components of insect exoskeletons. In addition to chitinase, a virus encoded protease, cathepsin, is expressed late in baculovirus infection. This protease aids in the breakdown of host cellular structure and eventually the integrity of the infected cadaver, thus maximizing baculovirus OB dispersion. Evidence for the importance of these two virus encoded enzymes in cadaver liquefaction comes from studies with recombinant viruses in which one or both of these genes have been knocked out [64]. Baculovirus constructs in which either or both genes have been deleted lead to virus infections in which cadavers remain intact for several days after death rather than displaying the typical "melting" symptomology.

\section{Discussion}

Chemical or biochemical modes of action are important in the development of effective biopesticides. As recognized in Glare et al. [5], current and future biopesticide research would benefit from an intensified focus on chemistry. A more complete understanding of the chemical basis of biological pest control can facilitate both more potent biopesticides. For example, biopesticide growth or cultivation conditions could be optimized. An improved understanding of biopesticide biochemistry could also lead to the development of enhanced formulations.

In contrast with older chemical or synthetic pest control strategies which generally utilized a single chemical, and hence a single mode of action, modern biopesticides seek to take a more holistic approach. This holistic approach recognizes that chemical modes of action are necessary or beneficial, but not always sufficient on their own, for successful pest control. For example, the herbicidal activity of macrocidins is complemented by host colonization by the living fungus [15]. Similarly, Bacillus subtilis controls plant disease through the combined action of anti-microbial metabolites [32] and competition with plant pathogens in the rhizosphere for space and nutrients [27]. Furthermore, baculoviruses kill insect pests by taking over the metabolic processes of the host insect for viral multiplication and transmission. This process involves both an active, replicating virus and the production of variety of enzymes and proteins that lead to enhanced infection and insect death [50]. Another component of the holistic approach used by some biopesticides is the presence of a suite of structurally distinct (though frequently related) secondary metabolites. This contrasts with synthetic pesticides which typically have only a single active ingredient. For example, pseudophomins A and B, both of which are produced by Pseudomonas fluorescens strain BRG100, show different activity $[65,66]$. Pedras et al. [66] found pseudophomins A to be a more effective bioherbicide, while pseudophomins B had greater activity as an anti-fungal compound. Biopesticides tend to be safer to non-target organisms than synthetic alternatives. Due to both their lower environmental risk and the fact that their effective use often depends on an understanding of the interaction with the environment as a whole (e.g. soil type, moisture, temperature) biopesticides are frequently a better fit with overall ecosystem or agro-ecosystem functioning.

The holistic, multi-pronged modes of action employed by biopesticides may have the additional benefit of delaying the development of pest resistance. Resistance to chemical pest control measures has been a challenge for decades (reviewed in Chandler et al. and Hollomon $[67,68])$. The use of synthetic pesticides with different modes of action is one tool for dealing with this problem [68]. While resistance to biopesticides remains relatively unstudied to date due to an infrequent occurrence, it could be a productive area for future research. Even when or if pests develop resistance to biopesticides, the fact that many biopesticides draw on modes of action distinct from synthetic pesticides (reviewed in the case of bioherbicides by Duke and Dayan [69]) would facilitate their use in integrated pest management in conjunction with synthetic pesticides. 
In exploring the question "are biopesticides which include a chemical mode of action more likely to succeed than those that do not?" we found it surprisingly difficult to find examples of biopesticides whose mode of action is truly free of a chemical or biochemical component. For example, Trichoderma mycofungicides are frequently touted as working through a combination of competition for nutrients with fungal plant pathogens and through mycoparasitism, actually rely on enzymes to penetrate and parasitize the fungal pathogens they control [70,71]. Hence, we conclude that chemistry and biochemistry play an indispensable role in biopesticide functioning. Chemical and biochemical processes act either during host attachment or infection, at later stages of pest control, or at multiple time points. Thus, research into the chemistry behind biopesticides has great potential to enhance the development of useful biopesticides.

\section{Competing interests}

The authors declare that they have no competing interests.

\section{Authors' contributions}

$\mathrm{MH}$ and $\mathrm{KLB}$ wrote the abstract, introduction, section on the bioherbicide Phoma macrostoma and the discussion. RKH composed the section on the biofungicide Bacillus subtilis. ME drafted the section on the bioinsecticidal nucleopolyhedroviruses. All authors read and approved the final manuscript

Received: 30 June 2014 Accepted: 16 September 2014

Published online: 28 November 2014

\section{References}

1. Saxena S, Pandey AK: Microbial metabolites as eco-friendly agrochemicals for the next millennium. Appl Microbial Biotechnol 2001, 55:395-403.

2. Bailey KL, Mupondwa EK: Developing microbial weed control products: commercialization, biological, and technological considerations. In Handbook of Sustainable Weed Management. Edited by Singh HP, Batish DR, Kohli RK. Binghamton NY USA: The Haworth press Inc:; 2006:431-473.

3. Kabaluk T, Gazdik K: Directory of Microbial Pesticides for Agricultural Crops in OECD Countries. Agriculture and Agri-Food. http://www4.agr.gc.ca/ resources/prod/doc/pmc/pdf/micro_e.pdf 2005, accessed November 2014.

4. Bailey $\mathrm{KL}$, Boyetchko SM, Längle T: Social and economic drivers shaping the future of biological control: a Canadian perspective on the factors affecting the development and use of microbial biopesticides. Biol Control 2010, 52:221-229.

5. Glare T, Caradus J, Gelernter W, Jackson T, Keyhani N, Kohl J, Marrone P, Morin L, Stewart A: Have biopesticides come of age? Trends Biotechnol 2012, 30:250-258.

6. Anonymous: Biopesticides acquire mainstream status. In Agrow World Crop Protaction News. United Kingdom: Informa; 2013.

7. Ash GJ: The science, art and business of successful bioherbicides. Biol Control 2010, 52:230-240

8. Bailey KL, Falk S: Turning research on microbial bioherbicides into commercial products - a Phoma story. Pest Technology 2011, 5(Special Issue 1):73-79.

9. Auld BA, Morin L: Constraints in the development of bioherbicides. Weed Technol 1995, 9:638-652.

10. Strange RN: Phytotoxins produced by microbial plant pathogens. Nat Prod Rep 2007, 24:127-144.

11. Bailey KL, Derby J: Fungal Isolates and Biological Control Compositions for the Control of Weeds. In US Patent Application. USA: Application Serial No. 60/294,475. Filed 20 May 2001; 2001

12. Zhou L, Bailey KL, Derby J: Plant colonization and environmental fate of the biocontrol fungus Phoma macrostoma. Biol Control 2004, 30:634-644.

13. Graupner PR, Carr A, Clancy E, Gilbert J, Bailey KL, Derby JA, Gerwick BC: The macrocidins: novel cyclic tetramic acids with herbicidal activity produced by Phoma macrostoma. J Nat Prod 2003, 66:1558-1561.
14. Bailey KL, Pitt WM, Falk S, Derby J: The effects of Phoma macrostoma on nontarget plant and target weed species. Biol Control 2011, 58:379-386

15. Bailey KL, Pitt WM, Leggett F, Sheedy C, Derby J: Determining the infection process of Phoma macrostoma that leads to bioherbicidal activity on broadleaved weeds. Biol Control 2011, 59:268-276.

16. Bailey KL, Boyetchko SM, Peng G, Hynes RK, Taylor WG, Pitt WM: Developing weed control technologies with fungi. In Advances in Fungal Biotechnology. Edited by Rai MIK. New Delhi, Bangalore: International Publishing House Pvt. Ltd; 2009.

17. Bailey KL, Pitt WM, Derby JA, Walter S, Taylor W, Falk S: Efficacy of Phoma macrostoma, a bioherbicide, for control of dandelion (Taraxacum officinale) following simulated rainfall conditions. Americas J Plant Sci Biotechnol 2010, 4(Special Issue 2):35-42.

18. De Crecy E, Jaronski S, Lyons B, Lyons TJ, Keyhani NO: Directed evolution of a filamentous fungus for thermotolerance. BMC Biotechnol 2009, 9:74.

19. Haynes C, Kirkwood RC: Studies on the mode of action of diflufenican in selected crop and weed species: basis of selectivity of pre- and early post-emergence applications. Pestic Sci 1992, 35:161-165.

20. Boger P: Mode of action of herbicides affecting carotenogenesis. $J$ Pestic Sci 1996, 21:473-478.

21. Berestetskiy AO: A review of fungal phytotoxins: from basic studies to practical use. Appl Biochem Microbiol 2008, 44:453-465.

22. Abriouel H, Franz CMAP, Omar NB, Galvez A: Diversity and applications of Bacillus bacteriocins. FEMS Microbiol Rev 2011, 35:201-232.

23. Nicholson WL, Munakata N, Horneck G, Melosh HJ, Setlow P: Resistance of Bacillus Endospores to extreme terrestrial and extraterrestrial environments. Microbiol Mol Biol Rev 2000, 64:548-572.

24. Nicholson WL: Roles of Bacillus endospores in the environment. Cell Mol Life Sci 2002, 59:410-416.

25. Cawoy H, Bettiol W, Fickers P, Ongena M: Bacillus-based biological control of plant diseases. In Pesticides in the Modern World - Pesticides use and Management. Edited by Stoytcheva DM. Rijeka, Croatia: InTech; 2011:273-302.

26. Choudhary DK, Johri BN: Interactions of Bacillus spp. and plants - with special reference to induced systemic resistance (ISR). Microbiol Res 2009, 164:493-513.

27. Huang XF, Chaparro JM, Reardon KF, Zhang R, Shen Q, Vivanco JM: Rhizosphere interactions: root exudates, microbes, and microbial communities. Botany 2014, 92:267-275.

28. Jack RW, Tagg JR, Ray B: Bacteriocins of gram-positive bacteria. Microbiol Rev 1995, 59:171-200.

29. Hynes RK, Leung GCY, Hirkala DLM, Nelson LM: Isolation, selection, and characterization of beneficial rhizobacteria from pea, lentil, and chickpea grown in western Canada. Can J Microbiol 2008, 54:248-258.

30. Lugtenberg B, Kamilova F: Plant-growth-promoting rhizobacteria. Annu Rev Microbiol 2009, 63:541-556.

31. Kwon JW, Kim SD: Characterization of an antibiotic produced by Bacillus subtilis JW-1 that suppresses ralstonia solanacearum. J Microbio/ Biotechnol 2014, 24:13-18.

32. Romero D, De Vicente A, Rakotoaly RH, Dufour SE, Veening JW, Arrebola E, Cazorla FM, Kuipers OP, Paquot M, Pérez-García A: The iturin and fengycin families of lipopeptides are key factors in antagonism of Bacillus subtilis toward Podosphaera fusca. Mol Plant Microbe Interact 2007, 20:430-440.

33. Ongena M, Jourdan E, Adam A, Paquot M, Brans A, Joris B, Arpigny JL, Thonart P: Surfactin and fengycin lipopeptides of Bacillus subtilis as elicitors of induced systemic resistance in plants. Environ Microbiol 2007, 9:1084-1090.

34. Jourdan E, Henry G, Duby F, Dommes J, Barthélemy JP, Thonart P, Ongena $\mathrm{M}$ : Insights into the defense-related events occurring in plant cells following perception of surfactin-type lipopeptide from Bacillus subtilis. Mol Plant Microbe Interact 2009, 22:456-468.

35. Bais HP, Fall R, Vivanco JM: Biocontrol of Bacillus subtilis against infection of Arabidopsis roots by pseudomonas syringae is facilitated by biofilm formation and surfactin production. Plant Physiol 2004, 134:307-319.

36. Romero D, Traxler MF, López D, Kolter R: Antibiotics as signal molecules. Chem Rev 2011, 111:5492-5505.

37. Stein T: Bacillus subtilis antibiotics: structures, syntheses and specific functions. Mol Microbiol 2005, 56:845-857.

38. Ongena $M$, Jacques P: Bacillus lipopeptides: versatile weapons for plant disease biocontrol. Trends Microbiol 2008, 16:115-125. 
39. Kinsella K, Schulthess CP, Morris TF, Stuart JD: Rapid quantification of Bacillus subtilis antibiotics in the rhizosphere. Soil Biol Biochem 2009, 41:374-379.

40. Willey JM, Van der Donk WA: Lantibiotics: peptides of diverse structure and function. Annu Rev Microbiol 2007, 61:477-501

41. Kunst F, Ogasawara N, Moszer I, Albertini AM, Alloni G, Azevedo V, Bertero MG, Bessieres P, Bolotin A, Borchert S, Borriss R, Boursier L, Brans A, Braun M, Brignell SC, Bron S, Brouillet S, Bruschi CV, Caldwell B, Capuano V, Carter NM, Choi SK, Codani JJ, Connerton IF, Cummings NJ, Daniel RA, Denizot F, Devine KM, Dusterhoft A, Ehrlich SD, et al: The complete genome sequence of the Gram-positive bacterium Bacillus subtilis. Nature 1997, 390:249-256.

42. Yajima A: Recent progress in the chemistry and chemical biology of microbial signaling molecules: Quorum-sensing pheromones and microbial hormones dedicated to the memory of Professor Youji Sakagami, 1948-2012. Tetrahedron Lett 2014, 55:2773-2780.

43. Beneduzi A, Ambrosini A, Passaglia LMP: Plant growth-promoting rhizobacteria (PGPR): their potential as antagonists and biocontrol agents. Genet Mol Biol 2012, 35:1044-1051.

44. Stein T, Borchert S, Conrad B, Feesche J, Hofemeister B, Hofemeister J, Entian KD: Two different lantibiotic-like peptides originate from the ericin gene cluster of Bacillus subtilis A1/3. J Bacteriol 2002, 184:1703-1711.

45. Rudrappa T, Czymmek KJ, Paré PW, Bais HP: Root-secreted malic acid recruits beneficial soil bacteria. Plant Physiol 2008, 148:1547-1556.

46. Nur Aishah AW, Hanina MN, Ismatul Nurul Asyikin I, Hairul Shahril M, Salina MR, Maryam MR, Abdul Jalil AK, Rosfarizan M: Antimicrobial protein produced by Bacillus subtilis ATCC 21332 in the presence of Allium sativum. Asian Pac J Tropical Dis 2014, 4:245.

47. Copping LG, Menn JJ: Biopesticides: a review of their action, applications and efficacy. Pest Manag Sci 2000, 56:651-676.

48. Glare TR, O'Callaghan M: Bacillus Thuringiensis: Biology, Ecology and Safety. Toronto, Canada: John Wiley and Sons; 2000.

49. Erlandson M: Insect pest control by viruses. Encyclopedia of Virology, Third Edition 2008, 3:125-133.

50. Rohrmann GF: Baculovirus Molecular Biology 3rd Edition. In National Library of Medicine (US). Bethesda (MD): National Center for Biotechnology Information; 2013.

51. Garavaglia MJ, Miele SA, Iserte JA, Belaich MN, Ghiringhelli PD: The ac53, ac78, ac101, and ac103 genes are newly discovered core genes in the family Baculoviridae. J Virol 2012, 86:12069-12079.

52. King LA, Possee RD: The Baculovirus Expression System, a Laboratory Guide. London, UK: Chapman \& Hall; 1992

53. Hegedus D, Erlandson M, Gillott C, Toprak U: New insights into peritrophic matrix synthesis, architecture, and function. Annu Rev Entomol 2009, 54:285-302.

54. Lepore LSRP, Granados RR: Enhancin, the granulosis virus protein that facilitates Nucleopolyhedrovirus (NPV) infections, is a metalloprotease. J Invertabrate Pathol 1996, 68:131-140

55. Popham HJR, Bischoff DS, Slavicek JM: Both Lymantria dispar Nucleopolyhedrovirus Enhancin genes contribute to viral potency. J Virol 2001, 75:8639-8648

56. Li Q, Li L, Moore K, Donly C, Theilmann DA, Erlandson MA: Characterization of Mamestra configurata nucleopolyhedrovirus enhancin and its functional analysis via expression in an Autographa californica M nucleopolyhedrovirus recombinant. J Gen Virol 2003, 84:123-132.

57. Peng J, Zhong J, Granados RR: A baculovirus enhancin increases the permeability of a mucosal midgut peritroohic matrix from lepidopteran larvae. J Insect Physiol 1999, 45:159-166.

58. Wang P, Granados RR: An intestinal mucin is the target substrate for a baculovirus enhancin. Proc Natl Acad Sci U S A 1997, 94:6977-6982.

59. Toprak U, Harris S, Baldwin D, Theilmann D, Gillott C, Hegedus DD, Erlandson MA: Role of enhancin in Mamestra configurata nucleopolyhedrovirus virulence: selective degradation of host peritrophic matrix proteins. J Gen Virol 2012, 93:744-753.

60. O'Reilly DR, Miller LK: Improvement of a baculovirus pesticide by deletion of the egt gene. Bio/Technology 1991, 9:1086-1089.

61. Cory JS, Myers JH: The ecology and evolution of insect baculoviruses. Annu Rev Ecol Evol Syst 2003, 34:239-272.

62. Hoover K, Grove M, Hughes DP, McNeil J, Slavicek JM: A gene for an extended phenotype. Science 2011, 333:1401
63. van Houte S, Ros VI, Mastenbroek TG, Vendrig NJ, Hoover K, Spitzen J, van Oers MM: Protein tyrosine phosphatase-induced hyperactivity is a conserved strategy of a subset of baculoviruses to manipulate lepidopteran host behavior. PLoS One 2012, 7:e46933.

64. Hawtin RE, Zarkowska T, Arnold K, Thomas CJ, Gooday GW, King LA, Kuzio JA Possee RD: Liquefaction of autographa californica nucleopolyhedrovirusinfected insects is dependent on the integrity of virus-encoded chitinase and cathepsin genes. Virology 1997, 238:243-253.

65. Quail JW, Ismail N, Pedras MSC, Boyetchko SM: Pseudophomins A and B, a class of cyclic lipodepsipeptides isolated from a Pseudomonas species. Acta Crystallogr Sect C: Cryst Struct Commun 2002, 58:268-271.

66. Pedras MSC, Ismail N, Quail JW, Boyetchko SM: Structure, chemistry, and biological activity of pseudophomins A and B, new cyclic lipodepsipeptides isolated from the biocontrol bacterium Pseudomonas fluorescens. Phytochemistry 2003, 62:1105-1114.

67. Chandler D, Bailey AS, Tatchell GM, Davidson G, Greaves J, Grant WP: The development, regulation and use of biopesticides for integrated pest management. Philos Trans R Soc Lond B Biol Sci 2011, 366:1987-1998.

68. Hollomon DW: Do we have the tools to manage resistance in the future? Pest Manag Sci 2012, 68:149-154.

69. Duke SO, Dayan FE: Modes of action of microbially-produced phytotoxins Toxins (Basel) 2011, 3:1038-1064.

70. Elad Y: Biological control of foliar pathogens by means of Trichoderma harzianum and potential modes of action. Crop Prot 2000, 19:709-714.

71. Markovich NA, Kononova GL: Lytic enzymes of Trichoderma and their role in plant defense from fungal diseases: a review. Appl Biochem Microbiol 2003, 39:389-400.

doi:10.1186/s40508-014-0018-x

Cite this article as: Crown copyright: The biochemistry behind

biopesticide efficacy. Sustainable Chemical Processes 2014 2:18.

Publish with ChemistryCentral and every
scientist can read your work free of charge
"Open access provides opportunities to our
colleagues in other parts of the globe, by allowing
anyone to view the content free of charge."
W. Jeffery Hurst, The Hershey Company.
- available free of charge to the entire scientific community
- peer reviewed and published immediately upon acceptance
- cited in PubMed and archived on PubMed Central
- yours - you keep the copyright
submit your manuscript here:
http://www.chemistrycentral.com/manuscript/

